\section{A NOVEL NATURALLY OCCURRING CARBAPENEM ANTIBIOTIC, AB-110-D, PRODUCED BY \\ KITASATOSPORIA PAPULOSA NOVO SP.}

Sir:

So far many carbapenem antibiotics have been discovered, such as thienamycins ${ }^{12}$, olivanic acids $^{2,3)}$, epithienamycins ${ }^{4)}$, PS series ${ }^{5,6)}$, OA6129 series $^{7)}$, C-19393 series ${ }^{8,8)}$, asparenomycins $^{10)}$, carpetimycins ${ }^{11)}$, pluracidomycins ${ }^{12)}$, SF-2103 series ${ }^{132}$ and SQ 27,860 ${ }^{14)}$. Most carbapenem antibiotics were produced by Streptomyces. Only SQ 27,860 was produced by Erwinia and Serratia. No other microorganism in any other genus has been reported to produce carbapenem antibiotics. Our screening program for novel carbapenem antibiotics from so-called 'rare actinomycetes' led to the discovery of a new strain named Kitasatosporia papulosa AB$110^{15)}$, which produces a novel carbapenem antibiotic named $A B-110-D$ together with epithienamycins $\mathrm{A}, \mathrm{B}, \mathrm{E}$ and $\mathrm{F}^{43}$. The structure of AB-110-D was elucidated as the $Z$ isomer of epithienamycin $E$ in the side chain. No carbapenem antibiotic having a $Z$ side chain has been isolated from the culture broth of any microorganism. This paper describes the fermentation, isolation, structure elucidation and characteristics of AB-110-D.

Carbapenem antibiotics were produced by submerged cultivation of strain AB-110 in a 500-liter fermentor containing 300 liters of SS medium supplemented with antifoam. SS medium contained starch $20 \mathrm{~g}$, glucose $5 \mathrm{~g}$, Soytone $12 \mathrm{~g}$, yeast extract $5 \mathrm{~g}, \mathrm{KH}_{2} \mathrm{PO}_{4} 1 \mathrm{~g}$, $\mathrm{CoSO}_{4} \cdot 7 \mathrm{H}_{2} \mathrm{O} \quad 0.006 \mathrm{~g}, \quad \mathrm{ZnSO}_{4} \cdot 7 \mathrm{H}_{2} \mathrm{O} \quad 0.003 \mathrm{~g}$, $\mathrm{MnSO}_{4} \cdot 4 \sim 5 \mathrm{H}_{2} \mathrm{O} 0.003 \mathrm{~g}, \mathrm{FeSO}_{4} \cdot 7 \mathrm{H}_{2} \mathrm{O} 0.003 \mathrm{~g}$ per liter adjusted to $\mathrm{pH} 7.0$. The fermentation was carried out at $28^{\circ} \mathrm{C}$ for 60 hours with an agitation speed of $310 \mathrm{rpm}$ and an air flow rate of 75 liters/minute.

Carbapenem antibiotics were detected by antibacterial activity and $\beta$-lactamase inhibitory activity during fermentation and isolation. The antibacterial activity was assayed by the paperdisc agar diffusion method using Comamonas terrigena AJ 2083 as the test organism. The $\beta$-lactamase inhibitory activity was also assayed by the paper-disc agar diffusion method using C. terrigena AJ 2083, penicillinase from Bacillus cereus (Sigma Chemical Co., penicillinase type I) and benzylpenicillin (Meiji Seika Kaisha, Ltd.).

The carbapenem antibiotics in the culture filtrate (220 liters) were absorbed on a column of anion exchange resin, Diaion SA 20A (30 liters, Mitsubishi Chemical Industries Limited), and eluted with $20 \mathrm{~mm}$ phosphate buffer $(\mathrm{pH} 7.0)$ containing $50 \% \mathrm{MeOH}, 1 \mathrm{M} \mathrm{NaCl}$ and $0.001 \%$ EDTA. The active eluate was desalted on a column of activated charcoal (15 liters, Wako Pure Chemical Industries Co.), and the desalted fraction was applied to a column of anion exchange resin, QAE-Sephadex A-25 (7 liters, Pharmacia Co.). After washing the column with $20 \mathrm{~mm}$ phosphate buffer ( $\mathrm{pH} 7.0$ ) containing $0.001 \%$ EDTA, elution was performed with a linear gradient of $0 \sim 1 \mathrm{M} \mathrm{NaCl}$ in the same buffer. Five active fractions, A, B, C, D and E (in the order of elution), were eluted from the column. Each fraction was desalted on a column of high porous resin, Diaion SP-207 (Mitsubishi Chemical Industries Limited), with 50\% $\mathrm{MeOH}$ and lyophilized to give crude powders respectively.

The crude powders of fractions $A, B, C$ and $E$ were further purified. AB-110-A, B, C and $E$ were isolated from the corresponding fractions and identified as epithienamycins A, B, F and $\mathrm{E}^{10)}$ respectively.

The crude powder of fraction $\mathrm{D}$ was further purified by column chromatography on Toyopearl HW-40 (400 ml, Tosoh Co.) with $20 \mathrm{~mm}$ phosphate buffer (pH 7.0) containing $0.001 \%$ EDTA. The active eluate was desalted and concd in vacuo. Final purification was achieved by preparative reverse phase HPLC on YMCPAK D-ODS-5 column $(20 \times 250 \mathrm{~mm}$, Yamamura Chemical Laboratories) with $5 \mathrm{~mm}$ phosphate buffer ( $\mathrm{pH} 7.0$ ) containing $8 \% \mathrm{MeOH}$. The peak fraction of AB-110-D was desalted on the same column with water followed by $50 \%$ $\mathrm{MeOH}$ and lyophilized to give $0.2 \mathrm{mg}$ of substantially pure $\mathrm{AB}-110-\mathrm{D}$ as the dipotassium salt.

HPLC retention times of those carbapenem antibiotics isolated from culture broth of $K$. papulosa AB-110 are shown in Table 1.

The UV spectrum of AB-110-D in water shows maxima at $229 \mathrm{~nm}$ and $305 \mathrm{~nm}$, and resembles those of $\mathrm{AB}-110-\mathrm{B}$ and $\mathrm{E}$ (epithienamycins $\mathrm{B}$ and $\mathrm{E}^{18)}$ respectively).

A molecular weight of 392 (the same as that 
of epithienamycin $\mathrm{E}^{16)}$ ) for $\mathrm{AB}-110-\mathrm{D}$ was suggested by the fast atom bombardment mass spectrum (FAB-MS): $m / z \quad 431(\mathrm{M}+\mathrm{K})^{+}, 469$ $(\mathrm{M}+2 \mathrm{~K}-\mathrm{H})^{+}$.

Table 1. Retention times of carbapenem antibiotics in HPLC.

\begin{tabular}{lc}
\hline & $\begin{array}{c}\text { Retention time } \\
\text { (minutes) }\end{array}$ \\
\hline AB-110-A (epithienamycin A) & 22.5 \\
AB-110-B (epithienamycin B) & 37.3 \\
AB-110-C (epithienamycin F) & 10.0 \\
AB-110-D & 25.2 \\
AB-110-E (epithienamycin E) & 19.3 \\
\hline
\end{tabular}

HPLC was carried out on a YMC R-ODS column $(4 \times 250 \mathrm{~mm})$ eluting with $2.5 \% \mathrm{MeOH}$ in $5 \mathrm{~mm}$ potassium phosphate buffer (pH 7.0) containing $1 \mathrm{mg} /$ liter of EDTA at flow rate of $1.0 \mathrm{ml}$ minute. The effluent was monitored with UV absorption at $300 \mathrm{~nm}$.
The ${ }^{1} \mathrm{H}$ NMR spectrum of AB-110-D is closely related to that of AB-110-E (epithienamycin $\mathrm{E}^{16)}$ ), as shown in Table 2, but some differences were observed in the chemical shift of the proton at $\mathrm{C}-12$ and in the coupling constant of vinyl protons at $\mathrm{C}-12$ and $\mathrm{C}-13$. The smaller coupling constant of the vinyl protons $(J=7.7 \mathrm{~Hz})$ suggested the presence of the $Z$ configuration for the $\mathrm{C}-12-\mathrm{C}-13$ double bond in the antibiotic. The configuration of the $\beta$-lactam hydrogen atoms at C-5 - C-6 in the antibiotic was determined to be cis by virtue of the observed coupling

Fig. 1. Structure of AB-110-D.<smiles>CC(=O)N/C=C/S/C=C1/C[C@H]2C(C(C)OS(=O)(=O)O)C(=O)N2C1=O</smiles>

Table 2. ${ }^{1} \mathrm{H}$ NMR chemical shifts of AB-110-D and AB-110-E (epithienamycin E).

\begin{tabular}{|c|c|c|}
\hline & AB-110-D & $\begin{array}{c}\mathrm{AB}-110-\mathrm{E} \\
\text { (epithienamycin } \mathrm{E}^{16)} \text { ) }\end{array}$ \\
\hline $9-\mathrm{H}_{3}$ & $1.52(\mathrm{~d}, J=6.1)$ & $1.50(\mathrm{~d}, J=6.5)$ \\
\hline $\mathrm{COCH}_{3}$ & $2.14(\mathrm{~s})$ & $2.04(\mathrm{~s})$ \\
\hline $4-\mathrm{H}_{\mathrm{a}}$ & $3.10(\mathrm{dd}, J=18,9)$ & $3.06(\mathrm{dd}, J=18,9)$ \\
\hline $4-\mathrm{H}_{\mathrm{b}}$ & $3.32(\mathrm{dd}, J=18,9)$ & $3.32(\mathrm{dd}, J=18,9)$ \\
\hline $5-\mathrm{H}$ & $4.31(\mathrm{dt}, J=5.5,9.3)$ & $4.29 \sim 4.85(\mathrm{~m})$ \\
\hline $6-\mathrm{H}$ & $3.87(\mathrm{dd}, J=5.5,9.3)$ & $3.84(\mathrm{dd}, J=5,10)$ \\
\hline $8-\mathrm{H}$ & $4.8(\mathrm{~m})$ & $4.29 \sim 4.85(\mathrm{~m})$ \\
\hline $12-\mathrm{H}$ & $5.71(\mathrm{~d}, J=7.7)$ & $6.07(\mathrm{~d}, J=13.8)$ \\
\hline $13-\mathrm{H}$ & $7.18(\mathrm{~d}, J=7.7)$ & $7.16(\mathrm{~d}, J=13.8)$ \\
\hline
\end{tabular}

The ${ }^{1} \mathrm{H}$ NMR spectrum was recorded at $400 \mathrm{MHz}$ in $\mathrm{D}_{2} \mathrm{O}$ with a Jeol JNM-GX-400 spectrometer. Chemical shifts are given in ppm relative to external DSS, and coupling constants are given in $\mathrm{Hz}$.

Table 3. Antimicrobial activity of AB-110-D.

\begin{tabular}{lcccccc}
\hline & \multicolumn{5}{c}{ MIC $(\mu \mathrm{g} / \mathrm{ml})$} \\
\cline { 2 - 6 } & $\begin{array}{c}\text { AB-110-A } \\
\text { (epithiena- } \\
\text { mycin A) }\end{array}$ & $\begin{array}{c}\text { AB-110-B } \\
\text { (epithiena- } \\
\text { mycin B) }\end{array}$ & $\begin{array}{c}\text { AB-110-C } \\
\text { (epithiena- } \\
\text { mycin F) }\end{array}$ & AB-110-D & $\begin{array}{c}\text { AB-110-E } \\
\text { (epithiena- } \\
\text { mycin E) }\end{array}$ \\
\hline Escherichia coli NIH JC-2 & 0.1 & 0.2 & 0.2 & 0.2 & 0.2 \\
Proteus vulgaris N-29 & 0.2 & 0.78 & 0.39 & 0.78 & 0.39 \\
P. mirabilis N-76 & 0.2 & 0.39 & 0.39 & 0.78 & 0.39 \\
Alcaligenes faecalis H-30 & 0.2 & 0.2 & 0.39 & 0.39 & 0.2 \\
Bacillus subtilis ATCC 6633 & 0.2 & 0.78 & 0.78 & 0.78 & 0.39 \\
Micrococcus luteus AJ 2020 & 0.2 & 0.78 & 0.78 & 0.78 & 0.39 \\
Staphylococcus aureus 209P & 0.2 & 0.39 & 0.39 & 0.39 & 0.39 \\
\hline
\end{tabular}

MICs $(\mu \mathrm{g} / \mathrm{ml})$ were determined by the serial agar dilution method using Brain Heart Infusion medium (Difco). Plates were inoculated with $1 \mu \mathrm{l}$ of an undiluted overnight broth culture $\left(\sim 10^{8} \mathrm{cfu}\right)$ and incubated at $37^{\circ} \mathrm{C}$ aerobically for 18 hours. The lowest concentration of antibiotic which inhibited macroscopic growth of bacteria was regarded as the MIC. 
Table 4. Stability of AB-110-D to $\beta$-lactamases.

\begin{tabular}{lcr}
\hline & $\begin{array}{c}\text { Penicillinase } \\
\text { from Bacillus } \\
\text { cereus }\end{array}$ & $\begin{array}{c}\text { Cephalosporinase } \\
\text { from Enterabacter } \\
\text { cloacae }\end{array}$ \\
\hline AB-110-A (epithienamycin A) & 50,000 & 200,000 \\
AB-110-B (epithienamycin B) & 25,000 & 200,000 \\
AB-110-C (epithienamycin F) & 150,000 & 700,000 \\
AB-110-D & 200,000 & 700,000 \\
AB-110-E (epithienamycin E) & 250,000 & 500,000 \\
Benzylpenicillin & 100 & 200 \\
Cephalosporin C & 100,000 & 100 \\
\hline
\end{tabular}

The stability of the antibiotics was determined microbiologically ${ }^{20)}$. Agar plates contained a range of concentrations of penicillinase or cephalosporinase with Comamonas terrigena AJ 2083. The concentration of $\beta$-lactamase that resulted in $50 \%$ inactivation of the antibiotic was determined. Values were expressed as relative stability, taking the stability for benzylpenicillin (penicillinase) or cephalosporin $\mathrm{C}$ (cephalosporinase) as 100 .

Table 5. $\beta$-Lactamase inhibitory activity of AB-110-D.

\begin{tabular}{ccc}
\hline & \multicolumn{2}{c}{$\mathrm{I}_{50}(\mathrm{ng} / \mathrm{ml})$} \\
\cline { 2 - 3 } & $\begin{array}{c}\text { Penicillinase } \\
\text { from Bacillus } \\
\text { cereus }\end{array}$ & $\begin{array}{c}\text { Cephalosporinase } \\
\text { from Enterobacter } \\
\text { cloacae }\end{array}$ \\
\hline AB-110-A (epithienamycin A) & 3.5 & 6.7 \\
AB-110-B (epithienamycin B) & 5.3 & 4.5 \\
AB-110-C (epithienamycin F) & 2.0 & 0.3 \\
AB-110-D & 1.5 & 0.2 \\
AB-110-E (epithienamycin E) & 3.5 & 3.1 \\
\hline
\end{tabular}

$\beta$-Lactamase inhibitory activity was determined by the spectrophotometric method of READING ${ }^{21}$. The concentration of the inhibitor required to cause $50 \%$ inhibition of hydrolysis of benzylpenicillin by penicillinase or cephalosporin $C$ by cephalosporinase were obtained when the inhibitor was preincubated with penicillinase or cephalosporinase for 10 minutes at $30^{\circ} \mathrm{C}$ before substrate addition.

constant $\left(J_{5,6}=5.5 \mathrm{~Hz}\right)$ in the ${ }^{1} \mathrm{H}$ NMR spectrum.

From those spectral data mentioned above, the structure of $\mathrm{AB}-110-\mathrm{D}$ was elucidated to be $(Z)-3$-[[2-(acetylamino)ethenyl]thio]-6-[1-(sulfooxy)ethyl]-7-oxo-1-azabicyclo[3,2,0]hept-2-enecarboxylic acid as shown in Fig. 1.

AB-110-D exhibits strong antimicrobial activity against Gram-positive and Gram-negative bacteria as shown in Table 3. Also AB-110-D exhibits high stability to penicillinase from $B$. cereus (penicillinase type I, Sigma Chemical Co.) and cephalosporinase from Enterobacter cloacae (penicillinase type III, Sigma Chemical Co.), as shown in Table 4. And AB-110-D exhibits powerful $\beta$-lactamase inhibitory activity against both penicillinase and cephalosporinase as shown in Table 5.

The compound, AB-110-D, has been synthesized chemically by Beecham's ${ }^{17)}$ and Takeda's researchers ${ }^{18,18)}$. However, there has been no report of production of this compound by any microorganism.

\section{Acknowledgments}

The authors wish to acknowledge Mr. H. SuzuKI, Mr. Y. Kurihara and Mr. S. Otomo in Fine Chemical Research Laboratories for conducting large scale fermentations, and Miss $\mathrm{H}$. ONOE and Miss $\mathrm{T}$. AKASHI in Analytical Research Laboratories for measuring ${ }^{1} \mathrm{H}$ NMR and FAB-MS spectrum.

YoshiHIRO NAKAMURA KoICHI IsHII

EIJI ONO

MASARU IsHIHARA

TORU KOHDA

YASUNORI YOKOGAWA

Hiroshiro ShibaI 
Applied Research Department, Central Research Laboratories, Ajinomoto Co., Inc., 1-1 Suzuki-cho, Kawasaki-ku, Kawasaki 210, Japan

(Received November 25, 1987)

\section{References}

1) Kahan, J. S.; F. M. Kahan, R. Goegelman, S. A. Currie, M. Jackson, E. O. Stapley, T. W. Miller, A. K. Mrller, D. Hendlin, S. Mochales, S. Hernandez, H. B. WoOnRufF \& J. Birnbaum: Thienamycin, a new $\beta$-lactam antibiotic. I. Discovery, taxonomy, isolation and physical properties. J. Antibiotics 32: $1 \sim$ 12,1979

2) Butterworth, D.; M. Cole, G. Hanscomb \& G. N. Rolinson: Olivanic acids, a family of $\beta$-lactam antibiotics with $\beta$-lactamase inhibitory properties produced by Streptomyces species. I. Detection, properties and fermentation studies. J. Antibiotics 32: 287 294, 1979

3) Box, S. J.; J. D. Hood \& S. R. Spear: Four further antibiotics related to olivanic acid produced by Streptomyces olivaceus: Fermentation, isolation, characterization and biosynthetic studies. J. Antibiotics 32: 1239 1247, 1979

4) Stapley, E. O.; P. J. Cassidy, J. Tunac, R. L. Monaghan, M. Jackson, S. Hernandez, S. B. Zimmerman, J. M. Mata, S. A. Currie, D. DAOUST \& D. HendiN: Epithienamycins novel $\beta$-lactams related to thienamycin. I. Production and antibacterial activity. J. Antibiotics 34: $628 \sim 636,1981$

5) Okamura, K.; S. Hirata, A. Koki, K. Hori, N. Shibamoto, Y. Okumura, M. Okabe, R. OKamoto, K. Kouno, Y. Fukagawa, Y. ShImauchi, T. IshikURA \& J. LeIN: PS-5, a new $\beta$-lactam antibiotic. I. Taxonomy of the producing organism, isolation and physicochemical properties. J. Antibiotics 32: 262 271, 1979

6) Shibamoto, N.; A. Koki, M. Nishino, K. NaKamura, K. Kiyoshima, K. OKamura, M. OKaBe, R. OKamoto, Y. FuKagawa, Y. ShimaUCHI, T. IsHIKuRA \& J. LEIN: PS-6 and PS-7, new $\beta$-lactam antibiotics. Isolation, physicochemical properties and structures. J. Antibiotics 33: 1128 1137, 1980

7) Okabe, M.; S. Azuma, I. Kojima, K. Kouno, R. OKAMOTO, Y. FuKagaWA \& T. Ishikura: Studies on the OA-6129 group of antibiotics, new carbapenem compounds. I. Taxonomy, isolation and physical properties. J. Antibiotics 35: $1255 \sim 1263,1982$
8) Imada, A.; Y. NoZaki, K. Kintaka, K. OKoNoGI, K. Kitano \& S. Harada: C-19393 S and $\mathrm{H}_{2}$, new carbapenem antibiotics. I. Taxonomy of the producing strain, fermentation and antibacterial properties. J. Antibiotics 33: $1417 \sim 1424,1980$

9) Harada, S.; Y. Nozaki, S. Shinagawa \& K. KitANo: C-19393 $\mathrm{E}_{5}$, a new carbapenem antibiotic. Fermentation, isolation and structure. J. Antibiotics 35: 957 962, 1982

10) Kawamura, Y.; Y. Yasuda, M. Mayama \& K. TANAKA: Asparenomycins A, B and C, new carbapenem antibiotics. I. Taxonomic studies on the producing microorganisms. J. Antibiotics 35: 10 14, 1982

11) Nakayama, M.; A. Iwasaki, S. Kimura, T. Mizoguchi, S. Tanabe, A. Murakami, I. Watanabe, M. OkUChI, H. Itoh, Y. SaIno, F. Kobayashi \& T. Mori: Carpetimycins A and $\mathrm{B}$, new $\beta$-lactam antibiotics. J. Antibiotics 33: $1388 \sim 1390,1980$

12) Tsuji, N.; K. Nagashima, M. Kobayashi, Y. Terui, K. Matsumoto \& E. Kondo: The structures of pluracidomycins, new carbapenem antibiotics. J. Antibiotics 35: 536 540, 1982

13) Ito, T.; N. Ezaki, K. Ohba, S. Amano, Y. Kondo, S. MiYadoh, T. Shomura, M. Sezaki, T. Niwa, M. KoJma, S. Inouye, Y. Yamada \& T. NIIDA: A novel $\beta$-lactamase inhibitor, $\mathbf{S F}$ 2103 A produced by a Streptomyces. J. Antibiotics 35: 533 535, 1982

14) Parker, W. L.; M. L. Rathnum, J. S. Welis, Jr., W. H. Trejo, P. A. Principe \& R. B. SYKES: SQ 27,860, a simple carbapenem produced by species of Serratia and Erwinia. J. Antibiotics 35: 653 660, 1982

15) Nakamura, Y.; E. ONo, T. Kohda \& H. SHIBAI: A novel naturally occurring carbapenem antibiotic, AB-110-D, produced by Kitasatosporia papulosa novo sp.; Taxonomic studies of producing microorganism. J. Gen. Appl. Microbiol., in preparation

16) Cassidy, P. J.; G. Albers-Schonberg, R. T. Goegelman, T. Miller, B. Arison, E. O. Stapley \& J. BirnbaUm: Epithienamycins. II. Isolation and structure assignment. J. Antibiotics 34: $637 \sim 648,1981$

17) Francis, C. D. (Beecham): $\beta$-Lactam compounds, their preparation and use. Eur. Pat. Appl. 8,885, Mar. 17, 1980

18) Harada, S.; S. Tsubotani \& M. Asai (Takeda): Isomerization of $\beta$-lactam compounds. Eur. Pat. Appl. 59,478, Sept. 8, 1982

19) Harada, S.; S. Tsubotani, M. Asai, K. Okonogi \& M. KONDO: Synthesis and biological activities of the $Z$ isomers of carbapenem antibiotics. J. Med. Chem. 26: $271 \sim 275,1983$ 
20) Nakamura, Y.; E. ONo, T. Kohda \& H. SHIBAI: A novel naturally occurring carbapenem antibiotic, AB-110-D, produced by Kitasatosporia papulosa novo sp.; highly targeted screening system for carbapenem antibiotics. J. Antibiotics, to submitted
21) READING, C. \& T. FARMER: The biochemical evaluation of $\beta$-lactamase inhibitors. In Antibiotic Assessment of Antimicrobial Activity and Resistance. Eds., A. D. Russell \& L. B. QUESNEL, pp. $141 \sim 159$, Academic Press, London, 1983 